\title{
A Venetian edition of Avicenna's works owned by Lonicer: Part I
}

This fine pair of volumes, ${ }^{1,2}$ one containing the text of a Latin edition of a number of Avicenna's works and the other an extensive and very detailed index of the contents of these texts published two years later, illustrates many aspects of the publishing and distribution of scholarly texts in the mid-sixteenth century. These copies are of the highest quality in all respects. The edition is the best contemporary text available printed and published by the house of luntae in Venice, one of the best contemporary printers, and bound, in Germany as we shall see, by a most skilful binder. In addition, this copy was owned by a famous botanist and physician, Adam Lonicer, and annotated by him.

\section{The author}

The physician, philosopher and polymath Abu 'Ali al-Husayn ibn 'Abd Allah ibn Sina whose life spanned the tenth to eleventh centuries was universally

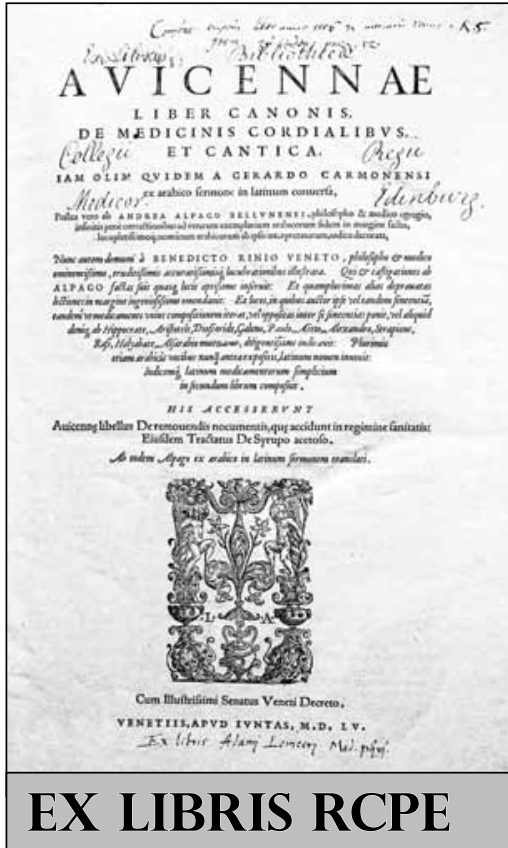

Avicenna, Liber canonis etc. Venice, 1555 known in mediæval and Renaissance Europe as Avicenna. He was born about 980 near Bukhara and probably died in 1037. His medical works are very heavily based on Greek sources and were one of the means by which knowledge of classical medical authors and commentary on their opinions became available to Western readers.

As well as the text of Avicenna's Canon - his best known medical work - which had been known in Latin translation since the Middle Ages, this edition contains a work on materia medica and 'songs', of which these Latin translations by Alpago were probably the first. I shall say nothing of the content of Avicenna's extensive medical works; suffice it to note that he was one of the principal medical authorities of Renaissance Europe and that translations of Avicenna were still in use as works of medical reference in the eighteenth century.

\section{The translators}

As with a number of Arabic texts, the first Latin translation of Avicenna's Canon was made in Moorish Spain. The title page of this edition says that it 'was certainly first translated by Gerard of Cremona' and the second Gerard of Cremona (Gerard of Sabloneta) is credited with a translation of the Canon in the thirteenth century. However, the title page text continues:

Later it was translated by Andrea Alpago Bellunensi, that most distinguished philosopher and physician, with abundant marginal corrections made with infinite pains from ancient Arabic texts, and with his interpretation of Arabic names added as an index...

This edition had yet more apparatus criticus added by another physician:

And now, finally, Benedictus Rinius, that most learned philosopher and physician of Venice, has added the fruit of his painstaking labours. For he has added to the commentary of Alpago his own comments, each in its proper place, and has corrected many erroneous readings in his marginal notes. And in those places where the author himself has given several opinions or descriptions of remedies, or where other authorities have expressed contrary opinions, he has inserted the opinions of Hippocrates, Aristotle, Dioscorides, Galen, Paul of Aegina, Aëtius of Amida, Alexander, Serapion, Rhazes, Haly Abbas - and translated these from the Arabic.* And for many Arabic words never before explained he has found Latin equivalents. He has also compiled a Latin index of the simples in the second book.

I have no information about Rinius but, from his address to the reader, he would seem to have been a meticulous scholar; he explains in detail the construction of his marginal notes and how he has dealt with doubtful readings of the text. His methods seem sensible and suitably cautious. Andrea Alpago of Belluno is better known and a figure of some interest. ${ }^{3} \mathrm{He}$ was probably born in 1459, studied in Padua and was physician to the Venetian Consulate in Damascus between about 1487 and 1517 . He returned to Venice and taught briefly in Padua. In Damascus Alpago studied Arabic and Islamic philosophy and became particularly interested in the works of Avicenna whose Canon and a number of opuscula he translated with notes and commentary. Alpago also compiled a Latin glossary of Arabic scientific terms which was included in a 1527 edition of the Canon and is also found at the end of the present edition as 'Andreae Bellunensis, Arabicorum nominum', with additions 'marked by asterisks' added by Rinius, one supposes from the information on the title page. 


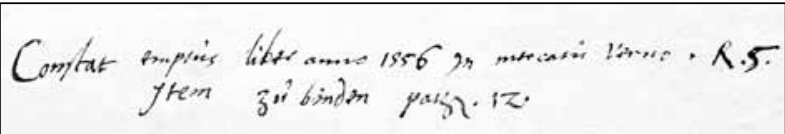

FIGURE I Lonicer's annotation on the title page of the text volume, describing its purchase at the Frankfurt Book Fair in 1556. Overlying letters from the College's manuscript Ex Libris, added to the page much later, have been removed.

In an age when erudition was often measured by the ability to quote extensively from many ancient authorities, a text such as Avicenna's Canon presented numerous difficulties and an equal number of opportunities. The difficulties were, of course, those of understanding the meaning of an author who wrote half a millennium earlier and in a then largely unknown tongue whose translation into Latin often contained opacities.

The opportunities were those of 'castigation' of the translation - critical review and correction. At best this would be based on new study of an original manuscript in the original language - Alpago's work on Arabic manuscripts of Avicenna is a good example - and might indeed lead to textual clarification. But a scholar could also make his mark by making exhaustive comparisons of the opinions of numerous other ancient authorities - or indeed the opinions of previous commentators on those authorities - on the same or similar topics and listing how they concurred with, or departed from, the opinion of the author under consideration. One may be sceptical of the extent to which this clarified the obscurities of the text, but it could be held to demonstrate the erudition of the commentator and it did provide a convenient key to the accumulated opinion on a topic.

Since Avicenna was himself often interpreting and commenting on the texts of classical medical writers in the state in which they were available to him in the early eleventh century, the process of translation followed by repeated castigation resulted in the construction of a huge edifice in which opinion was piled on opinion and argument set against argument. The text of this fine edition is such an edifice.

\section{Lonicer's notes}

The title page of the text volume carries two annotations in addition to the manuscript ex libris of the College. At the bottom of the page, just below the imprint and date, we have 'Ex libris Adami Loniceri Med. phys.', that is, from the library of Adam Lonicer, physician. Lonicer (I52886) was a pupil of Conrad Gesner and was primarily a botanist who later qualified in medicine (in 1554) and became town physician of Frankfurt. He married the daughter of the famous - and infamous - Frankfurt publisher of herbals, Christian Egenolff, whose business Lonicer seems to have taken over after Egenolff's death. Lonicer published a number of editions of his herbal and work on distillation, Herbarium, which was illustrated with the blocks that Gesner had prepared for his
Historia plantarum. ${ }^{4}$ Lonicer's name is now most familiar in the botanical name of the genus of honeysuckles, Lonicera.

At the top of the title page Lonicer has written some information about his acquisition of the book (Figure I):

Constat emptus liber anno 1556 in mercatu Verno. R. 5. Item zu binden pag[inarum?]. 12 .

('Bought at the spring fair in the year 1556 at a price of 5 ??. Also, for binding the sheets. 12.')

We know that Lonicer was living in Frankfurt at this date and there is no doubt that 'in mercatu Verno' refers to the spring Frankfurt book fair. The Frankfurt Book Fairs, a very important part of the sixteenth-century book trade, will be described in the second part of this article. The letter in the group at the end of the first line that appears to read ' $R$.5' is puzzling. From the context it appears to be a price, five of some unit of currency or coin. The word before 12 begins 'pag' and is clearly contracted; it is probably a contraction of paginarum. Thus the second phrase fairly certainly means that 12 units of currency - whatever the unit was - were paid for the binding of the sheets.

The book was published in 1555 and would have been bought new by Lonicer the following spring, at the Frankfurt Spring Book Fair. It would have been presented for sale not as a bound volume, but as a bundle of printed sheets which the buyer would then have bound into a volume to his requirements. However, the unit of currency is puzzling. It is difficult to think of a currency or coin beginning with $\mathrm{R}$ in use in Frankfurt or Venice, where the book was printed. Ducats, solidi, florins, libri, thalers would all make sense, but $R$ would not seem to refer to any of these. Whatever the unit, it seems likely that 12 of them were paid for the binding of the sheets since no other currency denominator appears in the next line. This would make the binding more expensive than the printed sheets.

But there is a further complication. The index volume was clearly bound to complement the text - the style is exactly the same, although the details of the tooled patterns are different. The index volume was not printed until I557 so cannot have been bought at the same fair as the text. It is possible that Lonicer added the annotation - or perhaps added to it the second line on the cost - after he had the index volume and was referring in the second line to the cost of binding both volumes. Interestingly, Lonicer has expressed 'to be bound' in German: zu binden.

The front paste-down (the paper pasted on to the inside of the front board) and first free endpaper of the text volume contain an attempt to derive the various components of Avicenna's Arabic name and a tortuous account of calculations of his birth and death dates. 
These were written by Lonicer, dated 26 August I558, and signed by him at the end 'Ad. Lon'. They are not of enough interest to the modern reader to be worth quoting in detail. The first part is concerned with Avicenna's name and depends on using the supposed names of Avicenna's father and grandfather to produce 'Alrais Abuhali Alhasen Ebenhali Ebensina', which Lonicer says signifies 'Prince whose father was Hali, Avicenna son of Hali who was the son of Sina'. More information about Avicenna's life is given in the Latin translation by Niccolo Massa of the biography attributed to Avicenna's pupil Sorsano, which is included in this edition and which Lonicer quotes in his manuscript.

The calculations of the dates appear to use only the information about Avicenna's dates which is contained in the book itself in the note to the reader provided by the printer (typographus lectori), so quite why Lonicer felt it necessary to carry out these calculations is not clear.

\section{Errata}

As do many books of the period, this one contains a list of typographical errors at the end; it is an indication of the care that the publisher took over the accuracy of his edition that the errors of the marginal notes are listed on a page of three dense columns of small type separately from the many fewer errors in the text itself.

The second part of this article will describe the highly decorated binding of the two volumes of this midsixteenth century Venetian edition (Figure 2), show how the sophisticated index in the second volume refers to the contents of the text volume and give a short account of the Frankfurt Book Fairs and their importance in the sixteenth century.

IML Donaldson, Honorary Librarian, RCPE (email: i.m.l.d@ed.ac.uk)

\section{REFERENCES}

I Avicenna. Avicennæ Liber canonis, De medicinis cordialibus, et Cantica iam olim quidem a Gerardo Carmonensi ex arabico sermone in latinum conversa.Trans. A Alpago. Venice: apud luntas; 1555.

2 Index in Avicennæ libros nuper venetiis editos... Venice: apud luntas; 1557.

3 Matsen HS. Review: Francesca Lucchetta. II medico e filosofo Bellunese Andrea Alpago (†1522) traduttore di Avicenna. Renaissance News 1965; 18:220-3. Available from: http://www. jstor.org/pss/2857946

4 Forbes RJ.A short history of the art of distillation: from the beginnings up to the death of Cellier Blumenthal. Leiden: EJ Brill; 1970. p.I38.

\section{NOTE}

* The text says 'Alsarabio mutuatur', which does not make sense. Alsarabio may well be a misprint for 'ab Arabico' which would make good sense in the context, meaning that the opinions had been 'converted' from the Arabic. I have translated it thus.

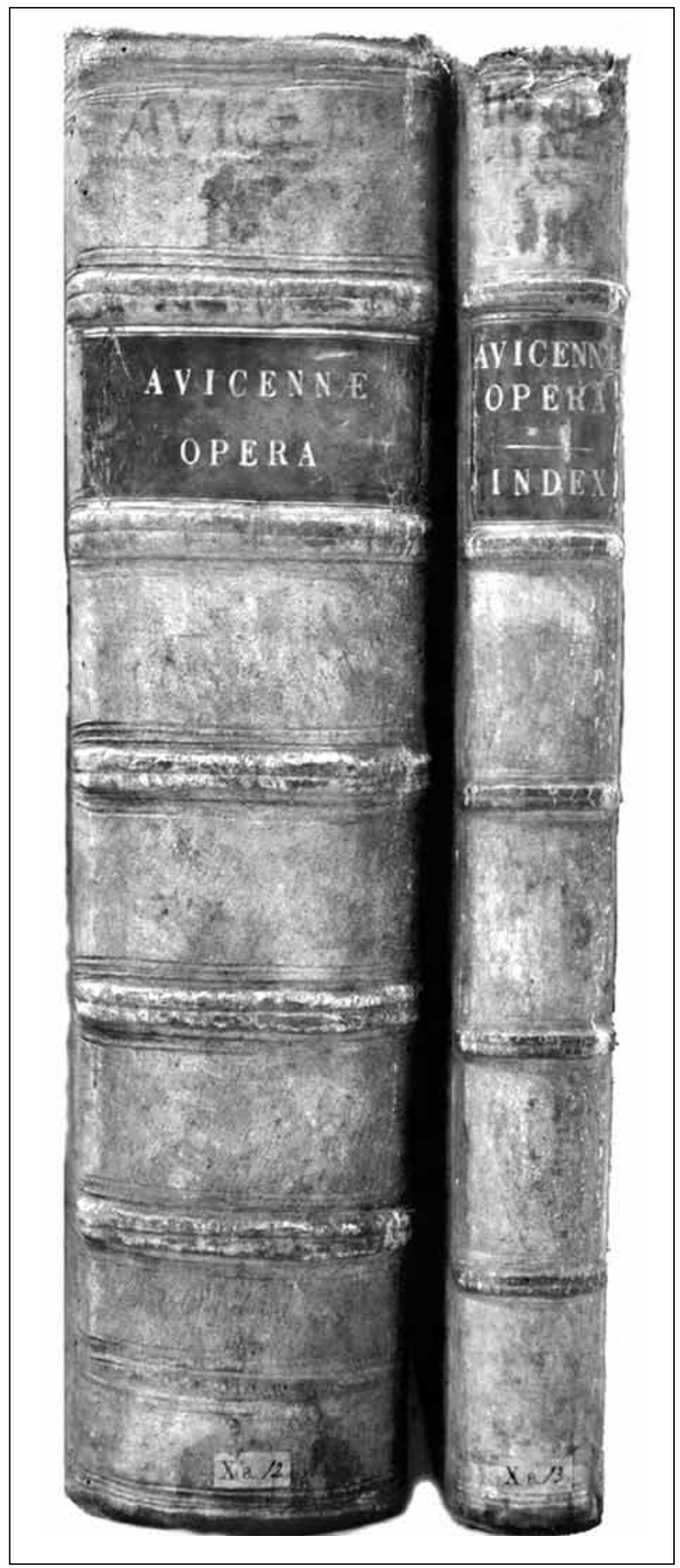

FIGURE 2 The two volumes as they appear on the shelf today; originally they would not have been shelved in this way. On the left is the volume of text from I555, on the right the index volume published two years later. The binding is contemporary with the publication. The labels carrying the titles in gold on a red background are relatively modern and certainly would not have been present in the sixteenth century. 